\title{
Causality in the Polish Housing Market: Evidence from Biggest Cities
}

\author{
Krzysztof Drachal \\ University of Warsaw \\ Faculty of Economic Sciences \\ Warsaw, Poland
}

\begin{abstract}
The aim of the paper is to examine the causal relationship between the real property prices in biggest Polish cities within VAR model framework. Both offer and transactional prices are used. Existing stock market, as well as primary market are analysed. The data are quarterly and taken from 17 biggest Polish cities. The analysed period is 2006-2015. Both VAR and VECM approaches were applied. Their limitations and possible predictions were discussed. A significant interaction between various regional real estate markets in Poland has been observed. However, the leading role of the capital city could not be confirmed by the methodology used.
\end{abstract}

Keywords: causality, property prices, Poland

JEL codes: $R 30$

\section{Introduction}

The real property prices in Poland have significantly increased in past few years. This situation is not just a Polish characteristic, but similar increases have been observed in other economies. Some researchers suggest that a house price bubble has occurred; in other words, that the situation cannot be explained on the basis of fundamental factors (Żelazowski, 2011).

Developing theoretical models for the real property market is a challenge and the same holds for the Polish market. The most important problem is the lack of a suitably long time series. Only recently, Narodowy Bank Polski (2015) has started to publish the reliable time series of house prices in biggest Polish cities. Of course this is also because the free market is relatively recent phenomena in Poland.

Certain researches suggest that the sudden house price increase (especially large between 2006 and 2007) was caused by certain socio-cultural factors. For example, the increased interest of consumers in moving to large cities, which are characterised by low unemployment, etc. (Żelazowski 2007). Indeed, there is some evidence that the difference in the standard of living between large cities and other regions of the country is continuously rising. Therefore, the increase in real property prices in cities is connected with what these cities offer to their inhabitants: easier access to education, healthcare, better chances of finding a good job, etc.

Yet, there are also some suggestions that the core of the price increase starts in selected, most dynamically expanding, cities and other regions just follow the trend 
(Drachal, 2014). Bełej and Kulesza (2014) applied various methods (Chebyshev distance, the damped harmonic oscillator model, etc.) and concluded that the capital city initiates the changes.

Therefore, it is interesting to analyse the causality of real property prices in Poland with a help of the vector autoregression model (VAR). It seems that such an analysis has not yet been done. It can help to identify regions which drive the house prices. In this research the analysis has been restricted to the linearity assumption. The aim of the paper is to examine the causal relationship between the real property prices in the biggest Polish cities within VAR and VECM model frameworks.

\section{Literature Review}

Holmes (2007) suggested that for the UK developed market there is no consistent long-run equilibrium relationship between various regions. However, cointegrated regions can be found (Ashworth and Parker, 1997). On the other hand, Drake (1995) concluded that development of real property prices is different in various regions of UK and the observed differences in price trends are statistically significant.

Meen (1999) postulated the existence of the so-called "ripple effect" in UK. In other words, the changes of prices in a certain region result in the changes in some other regions. However, Cook (2005a) noticed that the theoretical foundations of such conclusions can suffer from some significant statistical biases. Recently, Montagnoli and Nagayasu (2015) found that the house prices in UK can be grouped into four convergence clubs.

Zohrabyan et al. (2008) concluded that there is a significant cointegration between various regional property prices in the case of the US market. The "ripple effect" was also confirmed by Lean and Smyth (2012) on a bit more exotic, Malaysian, house market. Kyriazakou and Panagiotidis (2014) found that long-run causality in UK is mainly linear, but the short-run one is non-linear. They also found that the effect of the biggest town (London) on the other cities is the most important.

Holmes et al. (2011) found that that the speed of adjustment towards long-run equilibrium is inversely related with a distance. Similar conclusions were found by Holmes et al. (2017) for the Paris housing market. Bełej and Kulesza (2013) and Bełej (2013) used bifurcation theory to model how unexpected changes on real property market, even of small parameters, can result in large, structural changes.

The arguments for the causal relationship between house prices and credit policies of banks are also important. Indeed, macroeconomic factors vary significantly through regions. The causality tests of macroeconomic determinants and house prices were reported, for example, by Jadevicius (2016) for the Lithuanian housing market. However, the credit policies of banks are rather uniform. Of course, the relative value of the property to wages, credit risk, unemployment rate, etc. vary through regions. Still, the monetary policy, law regulations are quite uniform. Therefore, certain changes can gradually spread over all regions. It should be 
noticed that such interactions can be significant also at the multinational level (Horvatova and Kelemenova, 2013). The discussion of Printzi and Panagiotidis (2015) is also interesting in this context, as well as that of Nikolic (2015).

Lechowicz (2012) studied the impact of banking supervision and central bank actions in UK on the real estate market. These institutions occurred to have a very significant effect on the quantity of new housing space, investments, availability of credit, cost of credit, wealth effect, etc. Wealth effect and the impact of the liberalization of mortgage market on real property prices in UK were also thoroughly studied by Muellbauer and Murphy (2012).

One can also consider the relationship between the domestic financial market and real estate market (Okunev et al., 2000). Alexander and Barrow (1994) found a significant impact of real property prices in selected regions on the prices in other regions. They focused on the UK market and found that, especially, migrations play an important role in determining the causal directions (Petrisor, 2012; Strelecek et al., 2010).

Holmes and Grimes (2008) found that in the long term (i.e., between 1973 and 2006) house prices follow the same stochastic trend in various regions. The biggest agglomeration (i.e., London) determines the prices in all other regions. The smallest impact of London region is on the regions geographically far away from London. However, they were very careful that the methodology used and the choice of statistical tests heavily influenced the outcomes. Holly et al. (2011) confirmed these conclusions. Moreover, they suggested that even the prices in US significantly affect UK prices.

Similarly, Cook (2005b) observed that modelling with a certain asymmetric reaction can significantly affect the conclusions. Indeed, manipulating this reaction can lead to opposite outcomes. Meen (2002) also found important similarities between UK and US real property markets. In the case of long-run relationship this was also observed by Holly et al. (2010).

Yang et al. (2018) investigated the spillover in house prices in China. Their research was based on a high-dimensional generalized VAR method and covered the period between 2005 and 2015. Also, the biggest and middle size cities were considered. The spillover effect was confirmed to exist.

\section{Methodology and Data}

The causality was simply checked with the help of VAR model (Sims, 1980). This has several advantages, including flexibility and possible use of ordinary least squares for all equations separately. There is also no division into endogenous and exogenous variables. On the other hand, VAR model is considered a-theoretical.

There are problems with lag length selection. Moreover, for statistical test all components should be stationary. However, one can just examine the relationship 
between variables. Possible differencing (in order to achieve stationarity) can erase the long-run information (Adkins, 2013; Brooks, 2008; Hill et al., 2011).

Formally, VAR model (Vector Auto-Regression) can be described in the following way:

$y_{t}=c+A_{1} y_{t-1}+\cdots+A_{k} y_{t-k}+\varepsilon_{t}$

where $y_{t}$ represents the vector of variables. In the above (vector) equation there are $k$ lags for each variable; $A_{i}$ denotes the matrix of coefficients; $\varepsilon_{t}$ stands for the error terms (it is a vector). Each error term should have zero mean. $\varepsilon_{t} \varepsilon_{t}{ }^{T}$ should be a positive semi-definite matrix and for every $\mathrm{k}>0$ it should be $E\left(\varepsilon_{t} \varepsilon_{t}{ }^{T}\right)=0$, i.e., errors should not be autocorrelated (Lutkepohl, 2005).

The VAR model is applicable when all variables are stationary. Then each of the single equations (constituting the vector notation used for the sake of clarity) can be estimated by the standard Ordinary Least Squares (OLS) method. However, if the variables are not stationary, then: if they are not cointegrated, then VAR might be applied to their differences - but then the differences have to be stationary. However, if the variables are cointegrated, then the error correction term has to be included in VAR equation. Such models are called VECM (Vector Error Correction Model).

The data were taken from the database of Narodowy Bank Polski (2015). Quarterly data were used. The analysed the period starting in the 3rd quarter of 2006 and ending in the 2 nd quarter of 2015, resulting in 36 observations for each city. Both offer and transaction prices were analysed, as well as the primary (bought from and sold for the first time by a developer) and the existing stock markets (second and next transactions). The database consists of real estate prices in 17 biggest Polish cities, i.e., Białystok, Bydgoszcz, Gdańsk, Gdynia, Katowice, Kielce, Kraków, Lublin, Łódź, Olsztyn, Opole, Poznań, Rzeszów, Szczecin, Warszawa, Wrocław, and Zielona Góra.

Indeed, the selection of a suitable set of prices from the above options is an interesting problem. Łaszek and Widłak (2008) and Łaszek and Olszewski (2014) stressed that real property is not a homogenic product. Moreover, the market is not liquid enough and assets cannot be divided enough in comparison to other markets. The transactional prices can be artificially lowered because of the tax optimization, etc. All computations were done in gretl software. If not stated otherwise, the p-value in statistical tests is assumed to be $5 \%$.

\section{Results}

The analysis started from a VAR estimation. The lag length was taken to be just 1 . Indeed, for example, Akaike information criterion should be used, but the considered database consists of 36 observations only and taking more lags is impossible due to the numerical restrictions. 
The lack of long enough time series for Polish real estate market is a serious problem which cannot be currently overcome. A priori it is assumed that there is no long-run relationship between the variables. Therefore, VAR models were estimated, but for logarithms of prices. The stationarity was checked with ADF test with 9 lags and a constant.

The expression $l_{-} X$ denotes the logarithm of prices from town $X . l_{-} X \_l$ denotes the first lag of logarithm of prices from town $X$. P-values in Appendices 1-4 refer to the coefficients of the standard VAR model, i.e., coefficients $a_{1,1}, \ldots, a_{17,17}$ from the below system of equations:

l_Białystok $=$ const $+a_{1,1} l \_B i a ł y s t o k_{-} 1+\cdots+a_{1,17} l \_$ZielonaGora_1

l_ZielonaGora $=$ const $+a_{17,1} l_{-}$Białystok_1 $+\cdots+a_{17,17} l_{-}$ZielonaGora_1

In Table 2, symbol $d_{-} l_{-} X$ denotes the first difference of the logarithm of prices from town $X$. P-values from Table 2 refer to coefficients $\mathrm{a}_{1}, \ldots, \mathrm{a}_{17}$ from the below system of equations (the standard VECM model):

$$
\begin{aligned}
& d_{-} \text {__Białystok }=\text { const }+a_{1} \text { ErrorCorrection } \\
& \ldots \\
& d_{-} \text {l_ZielonaGora }=\text { const }+a_{17} \text { ErrorCorrection }
\end{aligned}
$$

In the case of primary market transaction prices, all time-series of log of prices were stationary (ADF test) at $5 \%$ significance level, except Białystok ( $p$-value $0.3692)$, Kraków (p-value 0.8987), Lublin ( $p$-value 0.204), Olsztyn ( $p$-value 0.6772 ), Opole ( $p$-value 0.7357), Rzeszów ( $p$-value 0.9979), Wrocław ( $p$-value $0.1955)$, and Zielona Góra ( $p$-value 0.5318).

Appendix 1 presents the results of estimation of VAR model for primary market and transaction prices. It should be noticed that only one lag was taken for each variable. Therefore, using F-test (for joint significance of all lags) is the same as performing t-test (for this one lag). Thus, the performed procedure is just the standard Granger causality testing.

In the case of primary market offer prices, all time-series of log of prices were stationary at 5\% significance level, except: Białystok ( $p$-value 0.3005), Gdańsk ( $p$ value 0.06127), Kraków ( $p$-value 0.2582), Łódź ( $p$-value 0.5877), Opole ( $p$-value $0.05719)$, Szczecin ( $p$-value 0.2756), Wrocław ( $p$-value 0.2787), and Zielona Góra ( $p$-value 0.3885$)$. This is quite similar as in the case of primary market transaction prices. 
Appendix 2 includes the results of estimation of VAR model for primary market and offer prices.

In the case of existing stock market transaction prices, all time-series of log of prices were stationary at 5\% significance level, except Gdynia ( $p$-value 0.5883), Kraków ( $p$-value 0.8715), Poznań ( $p$-value 0.6716), Warszawa ( $p$-value 0.7483), and Wrocław ( $p$-value 0.1824$)$. This is much better than in the case of primary market prices.

Appendix 3 presents the results of estimation of VAR model for existing stock market and transaction prices. In the case of the existing stock market offer prices, all time-series of log of prices were stationary at 5\% significance level, except: Katowice ( $p$-value 0.1482), Kielce ( $p$-value 0.8508), Olsztyn ( $p$-value 0.9317), Rzeszów ( $p$-value 0.3949), Warszawa ( $p$-value 0.7376$)$, and Wrocław ( $p$-value 0.1079 ). This is similar as in the case of the existing stock market transaction prices.

Appendix 4 shows the results of estimation of VAR model for the existing stock market and offer prices. Now, it can be seen that for short-run it is not the capital city (Warszawa), which influences the highest number of other cities (Table 1). Indeed, the most influencing city is Wrocław (which is also quite big) and surprisingly, also Olsztyn (a rather small town). Yet, this can be also the result of a high competition even on smaller regional markets (Kuryj-Wysocka and Wiśniewski, 2013). Warszawa (the capital city) is still one of the most influencing cities, but there are also some quite small ones like Kielce or Bydgoszcz whose influence is important. For example, a big city - Kraków - is not as influential as many other cities, for example, Rzeszów (a smaller town).

These results are quite surprising. However, they must be carefully interpreted. The application of VAR assumes stationarity (which was found to be violated in some cases) and lack of cointegration of variables (see, for example, the paper by Drachal (2015)). The lack of cointegration was assumed a priori without any tests herein. In this sense the paper of Kyriazakou and Panagiotidis (2014) was followed. Moreover, as it was indicated, there are problems with stationarity. More on stationarity and cointegration analysis for Polish property market can be found in Drachal (2015).

Therefore, the Engle-Granger test of cointegration was performed (4 lags were assumed). There is evidence for the cointegrating relationship if simultaneously the unit-root hypothesis is not rejected for the individual variables, and the unit-root hypothesis is rejected for the residuals from the cointegrating regression (Adkins, 2013; Fuller, 1976). At 5\% significance level, in the case of the existing stock market and offer prices, the first assumption was not met just for Kraków and Opole, but the second one was met. Therefore, there is evidence of cointegration for the existing stock market and offer prices.

At $5 \%$ significance level, in the case of the existing stock market and transaction prices, the first assumption was not met just for Kraków and Zielona Góra, but also 
the second one was not met. Therefore, there is no evidence of cointegration for the existing stock market and transaction prices.

At $5 \%$ significance level, in the case of the primary market and offer prices, the first assumption was not met for Białystok, Gdynia, Lublin, Poznań, Szczecin, and Zielona Góra. However, the second one was met. Therefore, there is quite a weak evidence of cointegration for the primary market and offer prices.

At $5 \%$ significance level, in the case of the primary market and transaction prices, the first assumption was not met for Bydgoszcz, Gdynia, Kielce, Lublin, Olsztyn, and Zielona Góra. However, the second one was met. Therefore, there is a weak evidence of cointegration for the primary market and transaction prices.

These results suggest that for the existing stock market and offer prices, the primary market and offer prices and the primary market and transaction prices, VECM model should be estimated instead of VAR model.

Table 1 Number of other cities influenced by certain variables (VAR)

\begin{tabular}{ccccc}
\hline & $\begin{array}{c}\text { transaction } \\
\text { prices and } \\
\text { primary } \\
\text { market }\end{array}$ & $\begin{array}{c}\text { offer prices } \\
\text { and primary } \\
\text { market }\end{array}$ & $\begin{array}{c}\text { transaction } \\
\text { prices and } \\
\text { existing stock } \\
\text { market }\end{array}$ & $\begin{array}{c}\text { offer prices } \\
\text { and existing } \\
\text { stock market }\end{array}$ \\
\hline \hline I_Bialystok_1 & 2 & 2 & 0 & 4 \\
\hline I_Bydgoszcz_1 & 5 & 5 & 5 & 5 \\
\hline I_Gdansk_1 & 4 & 2 & 2 & 2 \\
\hline I_Gdynia_1 & 4 & 3 & 6 & 2 \\
\hline I_Katowice_1 & 3 & 1 & 4 & 3 \\
\hline I_Kielce_1 & 0 & 7 & 5 & 6 \\
\hline I_Krakow_1 & 2 & 6 & 5 & 2 \\
\hline I_Lublin_1 & 2 & 5 & 2 & 2 \\
\hline I_Lodz_1 & 5 & 5 & 4 & 4 \\
\hline I_Olsztyn_1 & 6 & 5 & 1 & 1 \\
\hline I_Opole_1 & 3 & 3 & 1 & 5 \\
\hline I_Poznan_1 & 2 & 4 & 4 & 5 \\
\hline I_Rzeszow_1 & 1 & 8 & 2 & 2 \\
\hline I_Szczecin_1 & 3 & 9 & 3 & 2 \\
\hline I_Warszawa_1 & 6 & 5 & 5 & 5 \\
\hline I_Wroclaw_1 & 6 & 3 & 5 & 2 \\
\hline I_ZielonaGora_1 & 3 & 5 & 5 & 2 \\
\hline
\end{tabular}

Source: Own calculations in gretl

Table 2 indicates that on the existing stock market and offer prices many cities respond to disequilibrium between the selected region and other regions. On the other hand, on the primary market and offer prices only 5 cities have such a property. This can be, for example, the result of independent price policies of 
developers in different regions. However, much more regions have such a property, if transaction prices are considered. The results suggest that there is much interaction on the regional level of real estate markets.

Table 2 P-values for error correction term (VECM)

\begin{tabular}{cccc}
\hline & $\begin{array}{c}\text { existing stock } \\
\text { market and offer } \\
\text { prices }\end{array}$ & $\begin{array}{c}\text { primary market } \\
\text { and offer prices }\end{array}$ & $\begin{array}{c}\text { primary market } \\
\text { and transaction } \\
\text { prices }\end{array}$ \\
\hline d_I_Bialystok & $\mathbf{0 . 0 0 0 8}$ & $\mathbf{0 . 0 0 1 1}$ & $\mathbf{0 . 0 0 0 0}$ \\
\hline d_I_Bydgoszcz & 0.4226 & 0.4254 & $\mathbf{0 . 0 0 0 0}$ \\
\hline d_I_Gdansk & $\mathbf{0 . 0 0 0 0}$ & 0.8960 & $\mathbf{0 . 0 0 3 8}$ \\
\hline d_I_Gdynia & $\mathbf{0 . 0 2 7 3}$ & 0.1657 & $\mathbf{0 . 0 0 0 2}$ \\
\hline d_I_Katowice & 0.2877 & 0.7411 & 0.1228 \\
\hline d_I_Kielce & $\mathbf{0 . 0 0 0 2}$ & 0.2185 & 0.7596 \\
\hline d_I_Krakow & 0.3840 & $\mathbf{0 . 0 0 7 0}$ & $\mathbf{0 . 0 0 3 8}$ \\
\hline d_I_Lublin & $\mathbf{0 . 0 0 0 3}$ & $\mathbf{0 . 0 0 0 6}$ & 0.5966 \\
\hline d_I_Lodz & $\mathbf{0 . 0 0 0 6}$ & 0.5883 & $\mathbf{0 . 0 0 0 1}$ \\
\hline d_I_Olsztyn & $\mathbf{0 . 0 0 0 0}$ & $\mathbf{0 . 0 1 3 1}$ & $\mathbf{0 . 0 0 3 3}$ \\
\hline d_I_Opole & $\mathbf{0 . 0 0 0 0}$ & 0.8754 & 0.9571 \\
\hline d_I_Poznan & $\mathbf{0 . 0 0 1 6}$ & $\mathbf{0 . 0 4 9 5}$ & $\mathbf{0 . 0 0 6 1}$ \\
\hline d_I_Rzeszow & $\mathbf{0 . 0 0 0 0}$ & 0.2400 & 0.2075 \\
\hline d_I_Szczecin & $\mathbf{0 . 0 0 0 3}$ & 0.8362 & $\mathbf{0 . 0 0 0 0}$ \\
\hline d_I_Warszawa & $\mathbf{0 . 0 0 0 0}$ & 0.3095 & 0.1301 \\
\hline d_I_Wroclaw & $\mathbf{0 . 0 0 1 4}$ & 0.5872 & 0.6803 \\
\hline d_I_ZielonaGora & $\mathbf{0 . 0 2 8 0}$ & 0.3396 & $\mathbf{0 . 0 0 0 5}$ \\
\hline
\end{tabular}

Note: Statistically significant relationships are in bold. $10 \%$ p-value is assumed.

Source: Own calculations in gretl

The analysis suggested that there is a significant interaction between regional real estate markets. However, it was hard to estimate the direct causal relationship. First of all, certain problems with stationarity occurred, which indicate that VAR model assumptions are violated in some cases. Secondly, the analysed time series are very short. Unfortunately, there is a lack of more suitable data currently. These drawbacks can result in significant biases in the presented results.

\section{Conclusions}

The motivation for the research reported in this paper was to examine the causal relationship between the real property prices in biggest Polish cities. This task was quite hard as the available time-series are not long enough to perform all standard analyses. However, the VAR framework was applied. Offer and transactional prices were used. Additionally, both the existing stock market and primary market were 
analysed. However, due to some uncertainty about cointegrating properties of the time-series both VAR and VECM models were estimated.

A significant interaction between various regional real estate markets in Poland has emerged. However, the leading role of the capital city (Warszawa) cannot be confirmed by the used methodology. Yet, the chosen methodology could not be used in a pure and consistent way. Certain important problems were found. Moreover, the lack of long enough time series occurred to be a really hard problem to overcome. In the case of the existing stock market, almost every big city responds to the disequilibrium with other regional markets. However, on the primary market there are more cities which do not respond than the ones which do so. Because of the indicated suggestions and found difficulties, this research can serve as a starting point for some future, more detailed, research.

For example, the researcher having access to more frequent data can perform more meaningful analysis. If monthly data are used, the number of observations should be enough for reasonably performed cointegration tests, etc.

\section{References}

Adkins, L.C. (2013). Using Gretl for Principles of Econometrics. Stillwater OK: Oklahoma State University.

Alexander, C. and Barrow, M. (1994). Seasonality and Cointegration of Regional House Prices in the UK. Urban Studies, 31, pp. 1667-1689. DOI: $10.1080 / 00420989420081571$

Ashworth, J. and Parker, S. (1997). Modelling Regional House Prices in the UK. Scottish Journal of Political Economy, 44, pp. 225-246. DOI: 10.1111/14679485.00055

Bełej, M. (2013). Catastrophe Theory in Explaining Price Dynamics on the Real Estate Market. Real Estate Management and Valuation, 21, pp. 51-61. DOI: 10.2478/remav-2013-0026

Bełej, M. and Kulesza, S. (2013). Modeling the Real Estate Prices in Olsztyn Under Instability Conditions. Folia Oeconomica Stetinensia, 11, pp. 61-72. DOI: 10.2478/v10031-012-0008-7

Bełej, M. and Kulesza, S. (2014). Similarities in Time-series of Housing Prices on Local Markets in Poland. Real Estate Management and Valuation, 22, pp. 45-53. DOI: $10.2478 /$ remav-2014-0026

Brooks, C. (2008). Introductory Econometrics for Finance. Cambridge: Cambridge University Press. DOI: 10.1017/cbo9780511841644

Cook, S. (2005a). Regional House Price Behaviour in the UK: Application of a Joint Testing Procedure. Physica A, 345, pp. 611-621. DOI: 10.1016/j.physa.2004.07. 031 
Cook, S. (2005b). Detecting Long-run Relationships in Regional House Prices in the UK. International Review of Applied Economics, 19, pp. 107-118. DOI: 10.1080/0269217042000312632

Drachal, K. (2014). Property Prices and Regional Labor Markets in Poland. Singidunum Journal of Applied Sciences, 11, pp. 5-15. DOI: 10.5937/sjas11-4650

Drachal, K. (2015). Cointegration of Property Prices in Poland. Expert Journal of Economics, 3, pp. 1-4.

Drake, L. (1995). Testing for Convergence between UK Regional House Prices. Regional Studies, 29, pp. 357-366. DOI: 10.1080/00343409512331349023

Fuller, W.A. (1976). Introduction to Statistical Time Series. New York: Wiley. DOI: $10.1002 / 9780470316917$

Hill, R.C., Griffiths, W.E. and Lim, G.C. (2011). Principles of Econometrics. New York: Wiley.

Holly, S., Pesaran, M.H. and Yamagata, T. (2010). A Spatio-temporal Model of House Prices in the USA. Journal of Econometrics, 158, pp. 160-173. DOI: 10.1016/j.jeconom.2010.03.040

Holly, S., Pesaran, M.H. and Yamagata, T. (2011). The Spatial and Temporal Diffusion of House Prices in the UK. Journal of Urban Economics, 69, pp. 2-23. DOI: 10.1016/j.jue.2010.08.002

Holmes, M.J. (2007). How Convergent Are Regional House Prices in the United Kingdom? Some New Evidence from Panel Data Unit Root Testing. Journal of Economic and Social Research, 9, pp. 1-17.

Holmes, M.J. and Grimes, A. (2008). Is There Long-run Convergence among Regional House Prices in the UK? Urban Studies, 45, pp. 1531-1544. DOI: $10.1177 / 0042098008091489$

Holmes, M.J., Otero, J. and Panagiotidis, T. (2011). Investigating Regional House Price Convergence in the United States: Evidence from a pair-wise approach. Economic Modelling, 28, pp. 2369-2376. DOI: 10.1016/j.econmod.2011.06.015

Holmes M.J., Otero, J. and Panagiotidis, T. (2017). A Pair-wise Analysis of IntraCity Price Convergence within the Paris Housing Market. The Journal of Real Estate Finance and Economics, 54, pp. 1-16. DOI: 10.1007/s11146-015-9542-z

Horvatova, E. and Kelemenova, M. (2013). Analýza Vývoja Hypotekárnych Úrokových Sadzieb Vybraných Krajín Eurozóny. In: Globálna hospodárska a finančná kríza - quo vadis? Bratislava: FinStar, pp. 1-7.

Jadevicius, A. (2016). Macro-determinants of the Lithuanian Housing Market: A Test for Granger Causality. Journal of Baltic Studies, 47, pp. 385-398. DOI: 10.1080/01629778.2016.1141105 
Kuryj-Wysocka, O. and Wiśniewski, R. (2013). The Problem of Competition on Real Estate Market on the Example of the Local Housing Market in Olsztyn. Real Estate Management and Valuation, 21, pp. 69-76. DOI: 10.2478/remav-2013-0009

Kyriazakou, E. and Panagiotidis, T. (2014). Linear and Nonlinear Causality in the UK Housing Market: A Regional Approach. Economics and Business Letters, 3, pp. 288-297. DOI: 10.17811/ebl.3.4.2014.288-297

Lean, H.H. and Smyth, R. (2012). Regional House Prices and the Ripple Effect in Malaysia. Urban Studies, 50, pp. 895-922. DOI: $10.1177 / 0042098012459582$

Lechowicz, T. (2012). Wpływ Decyzji Nadzoru Bankowego i Banku Centralnego w Wielkiej Brytanii na Rynek Nieruchomości Mieszkaniowych w Latach 2001-2012. Roczniki Ekonomiczne Kujawsko-Pomorskiej Szkoły Wyższej w Bydgoszczy, 5, pp. 277-288, (in Polish).

Łaszek, J. and Olszewski, K. (2014). Zachowania Firmy Deweloperskiej na Rynku Mieszkań i Zagregowana Podaż. Kwartalnik Nauk o Przedsiębiorstwie, 32, pp. 7187, (in Polish).

Łaszek, J. and Widłak, M. (2008). Badanie Cen na Rynku Mieszkań Prywatnych Zamieszkałych Przez Właściciela z Perspektywy Banku Centralnego. Bank i Kredyt, 39, pp. 12-41.

Lütkepohl, H. (2005). New Introduction to Multiple Time Series Analysis. Berlin: Springer.

Meen, G. (1999). Regional House Prices and the Ripple Effect: A New Interpretation. Housing Studies 14, pp. 733-753. DOI: 10.1080/02673039982524

Meen, G. (2002). The Time-series Behavior of House Prices: A Transatlantic Divide? Journal of Housing Economics, 11, pp. 1-23. DOI: 10.1006/jhec.2001.0307

Montagnoli, A. and Nagayasu, J. (2015). UK house price convergence clubs and spillovers. Journal of Housing Economics, 30, pp. 50-58. DOI: $10.1016 / j$.jhe.2015.10.003

Muellbauer, J. and Murphy, A. (2012). Booms and Busts in the UK Housing Market. The Economic Journal, 445, pp. 1701-1727. DOI: $10.1111 / \mathrm{j} .1468-$ 0297.1997.tb00076.x

Narodowy Bank Polski (2015). Baza Cen Nieruchomości Mieszkaniowych, http://nbp.pl/publikacje/rynek_nieruchomosci/ceny_mieszkan.xls.

Nikolic, I. (2015). Price Determinants of Newly Built Dwellings in Serbia. Industrija, 43, pp. 105-116. DOI:10.5937/industrija43-8088

Okunev, J., Wilson, P. and Zurbruegg, R. (2000). The Causal Relationship between Real Estate and Stock Markets. Journal of Real Estate Finance and Economics, 21, pp. 251-261. DOI: $10.1111 / 1540-6229.00724$ 
Panagiotidis, T. and Printzis, P. (2015). On the Macroeconomic Determinants of the Housing Market in Greece: a VECM approach. GreeSE Papers, 88.

Petrisor, A.-I. (2012). Land Cover and Land Use Analysis of Urban Growth in Romania. Human Geographies - Journal of Studies and Research in Human Geography, 6, pp. 47-51. DOI: 10.5719/hgeo.2012.61.47

Sims, C. (1980). Macroeconomics and Reality. Econometrica, 48, pp. 1-48. DOI: $10.2307 / 1912017$

Strelecek, F., Lososova, J. and Zdenek, R. (2010). The Relations between the Rent and Price of Agricultural Land in the EU Countries. Agricultural Economics, 56, pp. 558-568.

Yang, J., Yu, Z. and Deng, Y. (2018). Housing Price Spillovers in China: A Highdimensional Generalized VAR Approach. Regional Science and Urban Economics, 68, pp. 98-114. DOI: 10.1016/j.regsciurbeco.2017.10.016

Zohrabyan, T., Leatham, D.J. and Bessler, D.A. (2008). Cointegration Analysis of Regional House Prices in U.S. In: Proceedings: 2007 Agricultural and Rural Finance Markets in Transition. St. Louis, Missouri.

Żelazowski, K. (2007). Zjawisko Bańki Cenowej w Kontekście Zmian a Polskim Rynku Mieszkaniowym. Studia i Materiały Towarzystwa Naukowego Nieruchomości, 15, pp. 139-150, (in Polish).

Żelazowski, K. (2011). Determinanty Zmian Cen Nieruchomości na Przykładzie Rynku Łódzkiego. Zeszyty Naukowe - Uniwersytet Ekonomiczny w Poznaniu, 192, pp. 179-189, (in Polish). 


\section{Appendices}

Appendix 1 P-values for VAR model of primary market transaction prices

\begin{tabular}{|c|c|c|c|c|c|c|c|c|c|c|c|c|c|c|c|c|c|}
\hline & (1) & (2) & (3) & (4) & (5) & (6) & (7) & (8) & (9) & (10) & (11) & (12) & (13) & (14) & (15) & (16) & (17) \\
\hline const & 0.7767 & 0.0966 & 0.0035 & 0.9783 & 0.0911 & 0.1560 & 0.0374 & 0.3601 & 0.1453 & 0.6949 & 0.1183 & 0.4056 & 0.0091 & 0.1403 & 0.0010 & 0.0026 & 0.7779 \\
\hline (1) I_Bialystok_1 & .5936 & 0.2764 & 0.9972 & 0.8880 & 0.9732 & 0.4504 & 0.7287 & 0.6101 & 0.4306 & 0.5492 & 0.3139 & 0.1814 & 0.6478 & 0.0378 & 0.2957 & 0.0238 & 0.1552 \\
\hline (2) I_Bydgoszcz_1 & 0.2575 & 0.0995 & 0.9532 & 0.7087 & 0.1785 & 0.0173 & 0.0674 & 0.0598 & 0.9958 & 0.0056 & 0.4867 & 0.3762 & 0.1914 & 0.8381 & 0.2825 & 0.3319 & 0.3057 \\
\hline (3) I_Gdansk_1 & 0.5347 & 0.9479 & 0.9516 & 0.7785 & 0.0694 & 0.6507 & 0.0469 & 0.6826 & 0.4922 & 0.0199 & 0.3681 & 0.5960 & 0.2331 & 0.1572 & 0.2414 & 0.0115 & 0.7606 \\
\hline (4) I_Gdynia_1 & 0.2556 & 0.1882 & 0.0128 & 0.1798 & 0.8308 & 0.0930 & 0.5487 & 0.2426 & 0.3753 & 0.3635 & 0.8880 & 0.6202 & 0.8345 & 0.4737 & 0.6551 & 0.3797 & 0.3206 \\
\hline (5) I_Katowice_1 & 0.7555 & 0.0047 & 0.3476 & 0.8321 & 0.6345 & 0.9507 & 0.3926 & 0.1248 & 0.5616 & 0.0333 & 0.8956 & 0.6866 & 0.8589 & 0.4395 & 0.0956 & 0.0794 & 0.5700 \\
\hline (6) I_Kielce_1 & 0.3423 & 0.4990 & 0.6366 & 0.2928 & 0.5354 & 0.4332 & 0.3503 & 0.9166 & 0.9013 & 0.4759 & 0.1918 & 0.2196 & 0.1792 & 0.4623 & 0.6277 & 0.4085 & 0.1129 \\
\hline (7) I_Krakow_1 & 0.2514 & 0.4545 & 0.1302 & 0.0539 & 0.4047 & 0.2453 & 0.0005 & 0.6239 & 0.1322 & 0.2050 & 0.8951 & 0.7710 & 0.1374 & 0.6060 & 0.7125 & 0.6191 & 0.6461 \\
\hline (8) I_Lublin_1 & 0.2626 & 0.3342 & 0.2924 & 0.6438 & 0.6767 & 0.3790 & 0.0695 & 0.9717 & 0.4475 & 0.7840 & 0.0791 & 0.2787 & 0.4657 & 0.2538 & 0.8992 & 0.9187 & 0.1231 \\
\hline (9) I_Lodz_1 & 0.5116 & 0.0250 & 0.0432 & 0.8034 & 0.6759 & 0.0413 & 0.1373 & 0.7267 & 0.8629 & 0.0383 & 0.1588 & 0.3441 & 0.7401 & 0.2406 & 0.2072 & 0.0008 & 0.3302 \\
\hline (10) I_Olsztyn_1 & 0.9944 & 0.5243 & 0.8021 & 0.0947 & 0.0054 & 0.0228 & 0.2025 & 0.8321 & 0.8381 & 0.0053 & 0.0431 & 0.5420 & 0.7581 & 0.7883 & 0.7189 & 0.0280 & 0.6642 \\
\hline (11) I_Opole_1 & 0.1038 & 0.6848 & 0.2337 & 0.0650 & 0.0107 & 0.7028 & 0.6004 & 0.5278 & 0.3457 & 0.6952 & 0.0558 & 0.2276 & 0.6251 & 0.4831 & 0.0042 & 0.7009 & 0.4632 \\
\hline (12) I_Poznan_1 & 0.7406 & 0.0058 & 0.0243 & 0.4436 & 0.1393 & 0.7371 & 0.3827 & 0.7497 & 0.6771 & 0.7537 & 0.3881 & 0.8409 & 0.9528 & 0.3433 & 0.3182 & 0.1711 & 0.7041 \\
\hline (13) I_Rzeszow_1 & 0.3223 & 0.5076 & 0.1333 & 0.4390 & 0.5617 & 0.2295 & 0.9691 & 0.7269 & 0.7894 & 0.0690 & 0.2700 & 0.8178 & 0.9784 & 0.9848 & 0.6437 & 0.4857 & 0.4542 \\
\hline (14) I_Szczecin_1 & 0.7908 & 0.0931 & 0.9267 & 0.8401 & 0.6996 & 0.3074 & 0.5236 & 0.8234 & 0.9363 & 0.2529 & 0.0855 & 0.1800 & 0.2315 & 0.9497 & 0.0037 & 0.0493 & 0.8256 \\
\hline (15) I_Warszawa_1 & 0.0722 & 0.0216 & 0.2778 & 0.3743 & 0.1631 & 0.6964 & 0.0668 & 0.6405 & 0.9280 & 0.0567 & 0.1331 & 0.0014 & 0.9775 & 0.9310 & 0.0018 & 0.9729 & 0.6730 \\
\hline (16) I_Wroclaw_1 & 0.0163 & 0.0003 & 0.2015 & 0.3619 & 0.0026 & 0.1926 & 0.4989 & 0.5192 & 0.0211 & 0.6232 & 0.7072 & 0.5250 & 0.1028 & 0.2123 & 0.5872 & 0.0279 & 0.0368 \\
\hline (17) I_ZielonaGora_1 & 0.8354 & 0.6458 & 0.2277 & 0.9820 & 0.0079 & 0.3110 & 0.7155 & 0.1248 & 0.9247 & 0.8822 & 0.3111 & 0.2943 & 0.0833 & 0.2928 & 0.0054 & 0.1689 & 0.7836 \\
\hline
\end{tabular}

Note: Statistically significant relationships are in bold. $10 \% \mathrm{p}$-value is assumed.

Source: Own calculations in gretl 
Appendix 2 P-values for VAR model of primary market offer prices

\begin{tabular}{|c|c|c|c|c|c|c|c|c|c|c|c|c|c|c|c|c|c|}
\hline & (1) & (2) & (3) & (4) & (5) & (6) & (7) & (8) & (9) & (10) & (11) & (12) & (13) & (14) & (15) & (16) & (17) \\
\hline const & 0.0598 & 0.0003 & 0.0399 & 0.0088 & 0.5583 & 0.4826 & 0.5376 & 0.0651 & 0.5945 & 0.1353 & 0.2249 & 0.0912 & 0.2283 & 0.1082 & 0.0011 & 0.0037 & 0.8693 \\
\hline (1) I_Bialystok_1 & 0.0738 & 0.1203 & 0.1402 & .2613 & .3484 & .1623 & 0.7176 & 0.1600 & 0.1454 & 0.7574 & 0.2427 & 0.2593 & 0.2657 & 0.7051 & 0.0120 & 0.3562 & 0.8844 \\
\hline (2) I_Bydgoszcz_1 & 0.1532 & 0.3837 & 0.7393 & 0.2493 & 0.8976 & 0.3520 & 0.0260 & 0.1999 & 0.0926 & 0.9908 & 0.0049 & 0.6777 & 0.7069 & 0.0381 & 0.6928 & 0.0951 & 0.1175 \\
\hline (3) I_Gdansk_1 & 0.1377 & 0.0205 & 0.1758 & 0.7811 & 0.1575 & 0.8791 & 0.2718 & 0.3519 & 0.6922 & 0.4583 & 0.5232 & 0.3541 & 0.2500 & 0.2023 & 0.1476 & 0.0044 & 0.7930 \\
\hline (4) I_Gdynia_1 & 0.5473 & 0.0894 & 0.7784 & 0.0755 & 0.9935 & 0.6342 & 0.8541 & 0.3914 & 0.5227 & 0.6558 & 0.1573 & 0.6409 & 0.5384 & 0.9702 & 0.0060 & 0.7488 & 0.4844 \\
\hline (5) I_Katowice_1 & 8249 & 0.7493 & 0.2324 & 0.2304 & 0.0946 & 0.6189 & 0.4697 & 0.2189 & 0.8529 & 0.6944 & 0.6705 & 0.5553 & 0.8112 & 0.5521 & 0.5523 & 0.1977 & 0.6863 \\
\hline (6) I_Kielce_1 & 0.2265 & 0.0497 & 0.3396 & 0.1392 & 0.2783 & 0.2362 & 0.0979 & 0.0234 & 0.0786 & 0.2636 & 0.4910 & 0.4731 & 0.3026 & 0.4168 & 0.0043 & 0.0333 & 0.0726 \\
\hline (7) I_Krakow_1 & 0.1878 & 0.0042 & 0.9875 & 0.1173 & 0.3772 & 0.9968 & 0.0008 & 0.0223 & 0.0684 & 0.0530 & 0.1175 & 0.6362 & 0.0207 & 0.9099 & 0.7685 & 0.3007 & 0.2635 \\
\hline (8) I_Lublin_1 & .0081 & 0.3263 & 0.1114 & 0.0856 & 0.7340 & 0.3506 & 0.1307 & 0.2685 & 0.1881 & 0.2385 & 0.3098 & 0.0221 & 0.9257 & 0.0489 & 0.0391 & 0.7784 & 0.5886 \\
\hline (9) I_Lodz_1 & 0.2356 & 0.0062 & 0.4898 & 0.0725 & 0.3078 & 0.4732 & 0.0651 & 0.5070 & 0.1488 & 0.9150 & 0.3323 & 0.3970 & 0.7157 & 0.0854 & 0.0149 & 0.4432 & 0.9559 \\
\hline (10) I_Olsztyn_1 & 0.0140 & 0.0389 & 0.2224 & 0.0102 & 0.8986 & 0.8235 & 0.0157 & 0.2295 & 0.1291 & 0.8732 & 0.7797 & 0.1866 & 0.2323 & 0.2740 & 0.0037 & 0.3093 & 0.6577 \\
\hline (11) I_Opole_1 & 0.4662 & 0.8959 & 0.4624 & 0.4826 & 0.4068 & 0.8403 & 0.3287 & 0.0368 & 0.2588 & 0.4081 & 0.0734 & 0.4726 & 0.5172 & 0.3409 & 0.0398 & 0.7154 & 0.2036 \\
\hline (12) I_Poznan_1 & 0.1184 & 0.5845 & 0.4960 & 0.2808 & 0.6476 & 0.7976 & 0.2310 & 0.5464 & 0.0089 & 0.6322 & 0.9540 & 0.5678 & 0.2574 & 0.0286 & 0.9101 & 0.0208 & 0.0002 \\
\hline (13) I_Rzeszow_1 & 0.0039 & 0.0249 & 0.4582 & 0.1824 & 0.4617 & 0.0687 & 0.0023 & 0.2194 & 0.1980 & 0.1522 & 0.0976 & 0.0039 & 0.0087 & 0.0081 & 0.6720 & 0.3520 & 0.7537 \\
\hline (14) I_Szczecin_1 & 0.0002 & 0.0105 & 0.2359 & 0.0076 & 0.0976 & 0.7670 & 0.0346 & 0.0028 & 0.3407 & 0.0269 & 0.1006 & 0.0765 & 0.6930 & 0.0115 & 0.1277 & 0.1401 & 0.2378 \\
\hline (15) I_Warszawa_1 & 0.0198 & 0.0597 & 0.1786 & 0.2402 & 0.8974 & 0.4908 & 0.1744 & 0.1584 & 0.3705 & 0.2379 & 0.9612 & 0.0876 & 0.2977 & 0.0138 & 0.0256 & 0.3561 & 0.9877 \\
\hline (16) I_Wroclaw_1 & 0.0140 & 0.0004 & 0.3098 & 0.0080 & 0.5604 & 0.9594 & 0.0232 & 0.1113 & 0.4303 & 0.1551 & 0.5248 & 0.6505 & 0.0009 & 0.1318 & 0.0344 & 0.0086 & 0.0001 \\
\hline (17) I_ZielonaGora_1 & 0.6692 & 0.0032 & 0.4451 & 0.1146 & 0.8907 & 0.4566 & 0.1736 & 0.7540 & 0.3262 & 0.7156 & 0.0105 & 0.3257 & 0.5814 & 0.8158 & 0.0367 & 0.7542 & 0.1068 \\
\hline
\end{tabular}

Note: Statistically significant relationships are in bold. $10 \% \mathrm{p}$-value is assumed.

Source: Own calculations in gretl 
Appendix 3 P-values for VAR model of the existing stock market transaction prices

\begin{tabular}{|c|c|c|c|c|c|c|c|c|c|c|c|c|c|c|c|c|c|}
\hline & (1) & (2) & (3) & (4) & (5) & (6) & (7) & (8) & (9) & (10) & (11) & (12) & (13) & (14) & (15) & (16) & (17) \\
\hline const & 0.4412 & 0.9009 & 0.5604 & 0.5574 & 0.2380 & 0.0109 & 0.0233 & 0.2151 & 0.2378 & 0.0009 & 0.0052 & 0.2186 & 0.1607 & 0.0413 & 0.0108 & 0.2546 & 0.1011 \\
\hline (1) I_Bialystok_1 & 4049 & .1442 & 0.9234 & 0.3819 & 0.4009 & .7938 & 0.7621 & 0.4602 & 0.8885 & 0.3689 & 0.2864 & 0.6430 & 0.8238 & 0.7873 & 0.4747 & 0.5710 & 0.4317 \\
\hline (2) I_Bydgoszcz_1 & 0.6400 & 0.3556 & 0.0155 & 0.0790 & 0.0349 & 0.4643 & 0.3459 & 0.5026 & 0.9029 & 0.5616 & 0.4365 & 0.8830 & 0.3420 & 0.7560 & 0.0690 & 0.8175 & 0.0281 \\
\hline (3) I_Gdansk_1 & .7337 & 0.4015 & 0.9462 & 0.7340 & 0.2594 & 0.0553 & 0.9552 & 0.6417 & 0.7749 & 0.5785 & 0.2274 & 0.2447 & 0.5018 & 0.8920 & 0.0467 & 0.9871 & 0.5452 \\
\hline (4) I_Gdynia_1 & 0.0433 & 0.5869 & 0.0272 & 0.2356 & 0.9282 & 0.7390 & 0.1485 & 0.0136 & 0.0048 & 0.4741 & 0.1920 & 0.7491 & 0.0929 & 0.3514 & 0.6117 & 0.8500 & 0.0756 \\
\hline (5) I_Katowice_1 & 3224 & 0.8834 & 0.0930 & 0.0873 & 0.0049 & 0.1830 & 0.1169 & 0.2023 & 0.1695 & 0.4164 & 0.6339 & 0.5316 & 0.3084 & 0.3312 & 0.0311 & 0.5415 & 0.2166 \\
\hline (6) I_Kielce_1 & 0.9512 & 0.8162 & 0.0562 & 0.9170 & 0.4963 & 0.0627 & 0.1785 & 0.0816 & 0.3731 & 0.3073 & 0.0418 & 0.7688 & 0.3216 & 0.8419 & 0.4592 & 0.1610 & 0.0694 \\
\hline (7) I_Krakow_1 & .3575 & 0.9536 & 0.8059 & 0.4206 & 0.3405 & 0.0629 & 0.7793 & 0.6919 & 0.7528 & 0.3888 & 0.5399 & 0.6870 & 0.7313 & 0.8618 & 0.0411 & 0.7720 & 0.2020 \\
\hline (8) I_Lublin_1 & 0.1634 & 0.6895 & 0.3507 & 0.0959 & 0.2881 & 0.7718 & 0.2197 & 0.0305 & 0.3396 & 0.1055 & 0.0442 & 0.0567 & 0.8123 & 0.3409 & 0.0026 & 0.3431 & 0.4913 \\
\hline (9) I_Lodz_1 & 0.1829 & 0.4902 & 0.9831 & 0.6528 & 0.2853 & 0.1285 & 0.6050 & 0.9249 & 0.2801 & 0.1261 & 0.0866 & 0.1707 & 0.1846 & 0.9049 & 0.4956 & 0.6367 & 0.0022 \\
\hline (10) I_Olsztyn_1 & 0.2701 & 0.5332 & 0.4915 & 0.2847 & 0.0510 & 0.0008 & 0.1350 & 0.7325 & 0.2435 & 0.0092 & 0.6943 & 0.0664 & 0.5762 & 0.6954 & 0.2928 & 0.2203 & 0.4722 \\
\hline (11) I_Opole_1 & 0.9405 & 0.8677 & 0.7356 & 0.3754 & 0.5212 & 0.1547 & 0.6343 & 0.8978 & 0.9246 & 0.7786 & 0.7114 & 0.5116 & 0.8073 & 0.0334 & 0.3670 & 0.4311 & 0.5566 \\
\hline (12) I_Poznan_1 & 0.4958 & 0.5762 & 0.9420 & 0.6557 & 0.2549 & 0.3570 & 0.5893 & 0.5460 & 0.4669 & 0.7822 & 0.0271 & 0.5458 & 0.4770 & 0.1881 & 0.6604 & 0.5802 & 0.2868 \\
\hline (13) I_Rzeszow_1 & 0.2146 & 0.4277 & 0.1190 & 0.5811 & 0.0856 & 0.6265 & 0.1036 & 0.9376 & 0.0097 & 0.4891 & 0.0260 & 0.2933 & 0.0065 & 0.8799 & 0.2990 & 0.9184 & 0.8125 \\
\hline (14) I_Szczecin_1 & 0.2916 & 0.1849 & 0.5813 & 0.1745 & 0.0920 & 0.1696 & 0.7100 & 0.4563 & 0.2584 & 0.9724 & 0.9443 & 0.6419 & 0.5539 & 0.0372 & 0.9360 & 0.8178 & 0.4909 \\
\hline (15) I_Warszawa_1 & 0.7614 & 0.7649 & 0.1361 & 0.2196 & 0.0375 & 0.4660 & 0.6452 & 0.0711 & 0.5498 & 0.3330 & 0.0978 & 0.5102 & 0.2724 & 0.6571 & 0.1304 & 0.4738 & 0.5195 \\
\hline (16) I_Wroclaw_1 & 0.0301 & 0.7187 & 0.8246 & 0.8981 & 0.1141 & 0.6132 & 0.0615 & 0.0315 & 0.7471 & 0.0536 & 0.0352 & 0.8709 & 0.3917 & 0.5691 & 0.3522 & 0.2322 & 0.1188 \\
\hline (17) I_ZielonaGora_1 & 0.4499 & 0.8496 & 0.4932 & 0.5331 & 0.0203 & 0.2149 & 0.6380 & 0.2642 & 0.8581 & 0.5736 & 0.0707 & 0.2640 & 0.2166 & 0.6575 & 0.9798 & 0.6912 & 0.7066 \\
\hline
\end{tabular}

Note: Statistically significant relationships are in bold. $10 \% \mathrm{p}$-value is assumed.

Source: Own calculations in gretl 
Appendix 4 P-values for VAR model of the existing stock market offer prices

\begin{tabular}{|c|c|c|c|c|c|c|c|c|c|c|c|c|c|c|c|c|c|}
\hline & (1) & (2) & (3) & (4) & (5) & (6) & (7) & (8) & (9) & (10) & (11) & (12) & (13) & (14) & (15) & (16) & (17) \\
\hline const & .2471 & 0.4583 & 0.0935 & 0.0028 & 0.1277 & 0.7642 & 0.0489 & 0.1139 & 0.6974 & 0.0176 & 0.0303 & 0.2298 & 0.0001 & 0.0651 & 0.0063 & 0.2887 & 0.0140 \\
\hline (1) I_Bialystok_1 & & & & & & & & & & & & 0.0717 & & & & 0.8461 & .3106 \\
\hline (2) I_Bydgoszcz_1 & 1892 & 0705 & 6300 & & .0634 & 0.7520 & .3566 & & 0.7791 & 0.8696 & 0.0322 & 0.7508 & 0.6647 & 0.5553 & .6952 & 0.0589 & .9985 \\
\hline (3) I_Gdans & & & & & & & & & .9969 & .9599 & 1371 & 0.0764 & 0.8089 & 0.5119 & .6377 & 0.4756 & 0.2601 \\
\hline (4) I_Gdynia_1 & 9855 & 0182 & & & & & & & & & & & & & & & \\
\hline (5) I_Katowice_1 & & & & & & & & & & & & & & & & & \\
\hline (6) I_Kielc & 0008 & & 0.0221 & & & 0.0501 & 0.1142 & & & 0.0150 & 0.3080 & 0.0081 & 0.4859 & 0.8270 & 0.0587 & 0.6847 & 0.5730 \\
\hline (7) I_Krakow_1 & & & & & & & & & & & & & & & & & \\
\hline (8) I_Lublin_1 & & 0.2127 & 0.9623 & 0.7234 & & 0.0245 & & & & 0.0252 & & 0.2893 & & & 0.5036 & 0.8217 & 0.4234 \\
\hline (9) I_Lodz_1 & & & & & & & & & & & & 0.0039 & 0.9408 & 0.8863 & 390 & & \\
\hline (10) I_Olsztyn_1 & 0.4272 & 0.3917 & 0.6503 & 0.0999 & & & & & & & & & & & 0.6050 & 0.0326 & 0.0130 \\
\hline (11) I_Opole_1 & .3544 & 0.1412 & 0.3245 & 0.7640 & 0.2505 & 0.9516 & 0.2401 & 0.1517 & 0.8708 & 0.2102 & 0.8086 & 0.4516 & 0.8985 & 0.8648 & 0.0528 & 0.2171 & 0.9548 \\
\hline (12) I_Poznan_1 & 0.1007 & 0.0850 & & & & & & & 0.9774 & & & 0.0142 & & & 0.7370 & 0.5535 & 0.5225 \\
\hline (13) I_Rzeszow_1 & 0.2879 & 0.5212 & 0.1835 & 0.0957 & 0.0011 & 0.0500 & 0.1389 & 0.8630 & 0.5990 & 0.1154 & 0.0040 & 0.0049 & 0.0004 & 0.0657 & 0.0017 & 0.3695 & 0.0009 \\
\hline (14) I_Szczecin_1 & & & & & & & & & & & & & & & & & \\
\hline (15) I_Warszawa_1 & 0.2439 & 0.9254 & 0.9251 & 0.8957 & 0.1340 & 0.0026 & 0.4188 & 0.9824 & 0.2687 & 0.6100 & 0.1220 & 0.1560 & 0.7527 & 0.0234 & 0.4908 & 0.4278 & 0.6024 \\
\hline (16) I_Wroclaw_1 & 0.2363 & 0.3699 & & & & & & & & & & & & & 0.2774 & 0.0042 & 0.2902 \\
\hline (17) I_ZielonaGora_1 & 0.0650 & 0.0078 & 0.2786 & 0.0745 & 0.6631 & 0.1410 & 0.8450 & 0.3850 & 0.3282 & & 0.0393 & 0.8490 & 0.0183 & 0.1123 & 0.6106 & 0.2495 & 0.2424 \\
\hline
\end{tabular}

Note: Statistically significant relationships are in bold. $10 \% \mathrm{p}$-value is assumed.

Source: Own calculations in gretl 